\title{
Identification of the Relationship between Rainfall and the CN Parameter in Western Carpathian Mountain Catchments in Poland
}

\author{
Dariusz Młyński *(D) and Andrzej Wałęga \\ Department of Sanitary Engineering and Water Management, University of Agriculture in Krakow, \\ Mickiewicza 24/28, 30-059 Krakow, Poland; andrzej.walega@urk.edu.pl \\ * Correspondence: dariusz.mlynski@urk.edu.pl; Tel.: +48-12-662-4041
}

Received: 16 October 2020; Accepted: 7 November 2020; Published: 10 November 2020

check for updates

\begin{abstract}
The aim of this study was to identify the form of the dependence describing the relationship between rainfall $(P)$ and the curve number $(C N)$ parameter using the Natural Resources Conservation Service (NRCS-CN) method in the mountain catchments of the Western Carpathians. The study was carried out in 28 catchments areas in the Western Carpathians in the Upper Vistula Basin, Poland. The study was conducted in the following stages: determination of the volume of the direct runoff using the NRCS-CN method, determination of the $P-C N$ relationship using asymptotic functions, kinetic equation and complementary error function; determination of the volume of the direct runoff from the catchment area, accounting for the correction of the decline; determination of the value of the efficiency coefficient of the analysed models. On the basis of the conducted study, a strong relationship was found between the direct runoff and the rainfall that caused it. The study showed that the empirical values of the $C N$ parameter differed from the values determined on the basis of the volume of rainfall and runoff. The vast majority of study catchments were characterised by a standard $P-C N$ relationship. The kinetic model was found to be the best model to describe the $P-C N$ relationship. The asymptotic model showed the greatest stability for high rainfall episodes. It was shown that the application of the catchment slope correction improved the quality of the NRCS-CN model.
\end{abstract}

Keywords: rainfall-runoff model; $C N$ parameter; catchment decline; asymptotic functions; surface runoff

\section{Introduction}

One of the most important tasks in engineering hydrology is determining the course of rainfall floods. Many methods are used for this, the use of which depends on the availability of hydrological data. In gauged catchments, design floods are determined on the basis of a seriesof observed flows. In the case of ungauged catchments, among the many methods, models based on the rainfall-runoff relationship are the most common [1-3]. Rainfall floods are dynamic processes influenced by many interrelated factors: rainfall intensity, direction of rainfall movement, catchment area, river network density, denivelation, geological structure, land use of catchment area, rainfall interception, infiltration, antecedent soil moisture, surface and subsurface flow and their pathways [4]. As a result, many methods have been developed to determine the volume of rainfall floods, taking into account the characteristics of their shaping $[5,6]$.

One of the most frequently used methods to describe the rainfall-runoff relationship is a procedure developed by the Natural Resources Conservation Service [7,8]. It is based on the runoff curve number $(C N)$, which is widely known as the NRCS-CN (formerly SCS-CN) method. The $C N$ parameter expresses the catchment's ability to form a surface runoff. In this method, the input signal is information on the 
rainfall course causing the runoff. On the other hand, the value of the $C N$ parameter depends on the infiltration capacity of the soil substrate, the use of the catchment area and the humidity conditions in the catchment before the rainfall causing the runoff. The popularity of the NRCS-CN method is mainly due to the simplicity of its application. Its use comes down to the determination of the value of the $C N$ parameter. However, this method also has several limitations. The main ones are, first of all, high sensitivity to changes in the $C N$ parameter; the lack of clear guidelines for determining the moisture conditions of the catchment area or the volume of initial rainfall losses; the lack of coefficients for taking into account significant drops in the catchment area [9-11]. Moreover, the NRCS-CN method does not allow for the determination of the course of infiltration over the time of rainfall, and it is problematic to determine the runoff for lower rainfall due to the fact that this method ignores the distribution of initial moisture in the soil [12]. In addition, it should be remembered that the NRCS-CN method allows to determine only surface runoff without taking into account the subsurface runoff, which may be the dominant form of total runoff, especially in catchments with high retention capacity [13-15]. It should also be emphasized that the original values of the $C N$ parameter were developed for small agricultural catchments. Hence, determining them for areas characterised by different use may lead to a greater error in the estimation of rainfall levels.

In recent years, many studies have been carried out on the effectiveness of the NRCS-CN method in the description of the runoff. Grimaldi et al. [10] proposed a new approach to determining the volume of net rainfall, combining the traditional NRCS-CN and the Green-Ampt equation (CN4GA). Caletka et al. [16] conducted analyses related to the dependence of the volume of initial abstraction on the volume of rainfall. They showed that the initial abstraction parameter was significantly different from the original one recommended by the NRCS. Moon et al. [17], Ebrahimian et al. [18] and Shi et al. [19] conducted studies related to determining the volume of runoff, taking into account the slopes of the catchments. They found that the surface runoff determined by the NRCS-CN method with adjustment for catchment slope had values much closer to the runoff observed compared to the original method. Hawkins [20] conducted a study on the relationship between the values of the $C N$ parameter and the volume of rainfall causing floods using the so-called asymptotic functions. The values of $C N$ parameter were estimated as a function of the observed episodes of rainfall-runoff. On the basis of observations, he distinguished three basic relationships between the $C N$ parameter and rainfall $(C N-P)$. The most common was the so-called "standard" behaviour, where with low rainfall, high values of the $C N$ parameter occur and they gradually decrease with increasing rainfall, heading towards a constant asymptotic value of $C N$ with increasing rainfall. The second is "complacent" behaviour. It is characterised by decreasing values in the $C N$ parameter with increasing rainfall. However, there is no tendency here to approach the constant $C N$ value. The last type of behaviour is "violent", where for high rainfall, the $C N$ values are apparently constant, except for very low episodes for which the $\mathrm{CN}$ suddenly increases [21]. A study related to determining the $\mathrm{CN}-\mathrm{P}$ relationship with the use of asymptotic functions was also conducted by Wałega et al. [22], where the analyses were performed for forest catchments. In the work of Ebrahimian et al. [23], these functions were used to estimate $C N$ in urban catchments. Ryu et al. [24] integrated the asymptotic model with indicators describing the direct runoff from the catchment area. Velásquez-Valle et al. [25] used the asymptotic functions to determine the rainfall-runoff relationship in the catchments of a semi-arid climate. Santikari and Murdoch [26] investigated the effect of the heterogeneity of the catchment area and the variable values of initial rainfall losses on the values of the $C N$ parameter using asymptotic functions.

In Poland, studies regarding the effectiveness of the NRCS-CN method have been carried out. Krajewski et al. [27] showed that estimated initial abstraction ratios varied between storm events and seasons, and they were most often lower than the original value of 0.20 . In the case of large events, the initial abstraction ratio in the catchment approached a constant value after the rainfall depth exceeded a certain threshold value. Hence, when using the original NRCS-CN method, the initial abstraction ratio should be locally verified. Młyński et al. [28] showed that the CN4GA method can be successfully applied to determine the course of rainfall in Polish small mountain catchments. Wałęga et al. [29] 
compared the direct outflow calculated by modified and original NRCS-CN methods for mountains and highland catchments in the Upper Vistula Basin and lowland catchments in South Carolina, USA. They claimed that direct outflow calculated by the original NRCS-CN method was underestimated in comparison to the observed ones for most of the analysed episodes. Kohnová et al. [30] investigated the L-moment based regional approach to curve numbers for Slovak and Polish Carpathian catchments. They showed that, mainly, introducing a common regional $C N$ provides an opportunity to apply this procedure in catchments of similar soil-physiographic characteristics and to verify existing tabulated CN. In the work Rutkowska et al. [31], the probabilistic properties of a curve number were studied. The authors showed that for $\mathrm{CN}$, a generalized extreme value distribution was identified as the best fit in most of the catchments.

Bearing in mind the limitations of the original NRCS-CN method, the aim of this study was to identify the form of dependencies describing the relation between rainfall and the $C N$ parameter in the mountain catchments of the Western Carpathians. The analyses were performed for the Upper Vistula Basin, Poland. The conducted study allowed for the verification of the $C N$ parameter for the examined area. The calculations were made using asymptotic functions. So far, studies for this region have been conducted for individual catchments. It should be emphasized that due to the geological structure and the structure of land use, this area is one of the most flood-prone in the entire region. Hence, the analyses carried out, covering a wide area of this region, made it possible to describe the regularities for the $P-C N$ relationship and, thus, to describe the regularities that shape rainfall. It should be emphasized that in this area no studies have been carried out to date on the impact of the decrease in the catchment area on the values of the $C N$ parameter. Hence, such analyses were additionally taken into account, which is a novelty in this conducted study. As part of the study, the following hypotheses were formulated: (i) there is a difference between the empirical $C N$ and that observed in the Carpathian catchments; (ii) the relationship between the volume of rainfall and the observed $C N$ in the Carpathian catchments is inversely proportional; (ii) there is some volume of rainfall for which the $C N$ parameter stabilises for the Carpathian catchments; (iv) the decline plays a significant role in influencing the volume of runoff from the catchment area.

\section{Study Area}

The study was carried out for 28 catchments in the Upper Vistula Basin (Poland). This area is located in Central Europe. The Upper Vistula Basin constitutes approximately $25 \%$ of the total area of the Vistula catchment area and covers approximately $15 \%$ of the total area of Poland. The Upper Vistula Basin is formed by three basic physiographic units: the Carpathians, uplands and plains [32]. Due to the geological structure and the forms of land use, this area is one of the most flood-prone in the entire region. Figure 1 shows the location of studied catchments area. The selected catchments are representative for each physiographic unit. Table 1 summarises the values of the basic physiographic and meteorological characteristics of the catchment areas: $A$-catchment area, $L$-length of the main watercourse, $\Psi$ —average slope of the catchment area, $D$-river network density, $N$ —soil impermeability index, $U R B$ - urban areas, $A G R$ —agricultural areas, FOR — forest and semi-natural areas, WET — wetlands, WAT - water bodies, $P_{\text {ave }}$-average annual rainfall in the catchment area and $t_{\text {ave }}$-average annual temperature in the catchment area. 


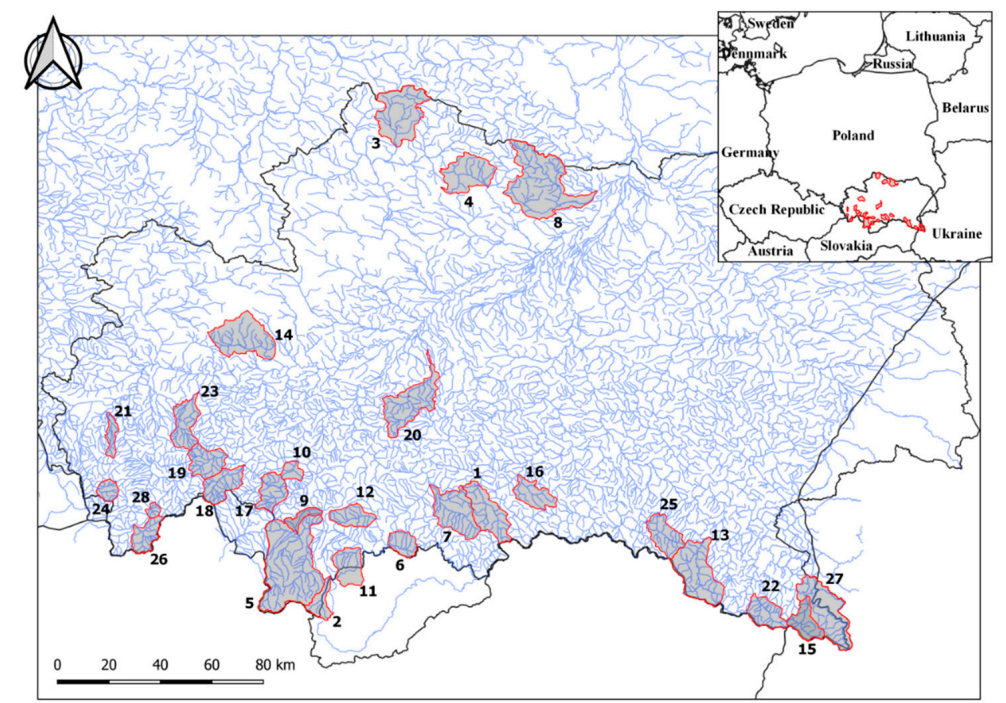

Figure 1. Location of the research catchment area in the Upper Vistula Basin.

Table 1. Values of physiographic and meteorological characteristics of research catchments.

\begin{tabular}{|c|c|c|c|c|c|c|c|c|c|c|c|c|c|}
\hline \multirow{2}{*}{ Code } & \multirow{2}{*}{ River } & \multirow{2}{*}{$\underset{\left(\mathrm{km}^{2}\right)}{A}$} & \multirow{2}{*}{$\begin{array}{c}L \\
(\mathbf{k m})\end{array}$} & \multirow{2}{*}{$\begin{array}{l}\Psi \\
(-)\end{array}$} & \multirow{2}{*}{$\begin{array}{c}D \\
\left(\mathbf{k m} \cdot \mathbf{k m}^{-2}\right)\end{array}$} & \multirow{2}{*}{$\begin{array}{l}N \\
(-)\end{array}$} & \multicolumn{5}{|c|}{ Land Use (\%) } & \multirow{2}{*}{$\begin{array}{l}P_{\text {ave }} \\
(\mathrm{mm})\end{array}$} & \multirow{2}{*}{$\begin{array}{l}t_{\text {ave }} \\
\left({ }^{\circ} \mathrm{C}\right)\end{array}$} \\
\hline & & & & & & & URB & AGR & FOR & WET & WAT & & \\
\hline 1 & Biała & 212.2 & 31.7 & 0.039 & 1.8 & 0.85 & 2 & 45 & 53 & 0 & 0 & 890 & 6.9 \\
\hline 2 & Białka & 78.0 & 19.9 & 0.159 & 1.3 & 0.48 & 0 & 0 & 98 & 0 & 2 & 1539 & 2.6 \\
\hline 3 & Bobrza & 311.6 & 40.2 & 0.046 & 1.1 & 0.52 & 17 & 44 & 39 & 0 & 0 & 649 & 7.8 \\
\hline 4 & Czarna & 221.2 & 22.1 & 0.016 & 0.9 & 0.46 & 1 & 45 & 54 & 0 & 0 & 629 & 7.8 \\
\hline 5 & Dunajec & 685.1 & 50.5 & 0.062 & 2.1 & 0.82 & 6 & 52 & 42 & 1 & 0 & 1023 & 5.4 \\
\hline 6 & Grajcarek & 86.0 & 15.6 & 0.084 & 1.4 & 0.80 & 4 & 21 & 74 & 0 & 0 & 765 & 7.3 \\
\hline 7 & Kamienica & 237.7 & 34.5 & 0.055 & 1.9 & 0.82 & 5 & 36 & 59 & 0 & 0 & 901 & 7.8 \\
\hline 8 & Koprzywianka & 518.6 & 70.3 & 0.013 & 1.1 & 0.64 & 3 & 74 & 23 & 0 & 0 & 613 & 7.6 \\
\hline 9 & Lepietnica & 50.3 & 19.5 & 0.087 & 2.6 & 0.78 & 28 & 27 & 45 & 0 & 0 & 873 & 6.0 \\
\hline 10 & Lubieńka & 48.1 & 4.7 & 0.074 & 2.2 & 0.80 & 0 & 56 & 44 & 0 & 0 & 902 & 7.0 \\
\hline 11 & Niedziczanka & 137.8 & 22.0 & 0.059 & 1.4 & 0.80 & 3 & 52 & 45 & 0 & 0 & 978 & 5.5 \\
\hline 12 & Ochotnica & 109.0 & 22.8 & 0.084 & 2.1 & 0.79 & 1 & 27 & 72 & 0 & 0 & 830 & 8.7 \\
\hline 13 & Osława & 307.0 & 38.9 & 0.034 & 2.3 & 0.86 & 1 & 23 & 76 & 0 & 0 & 911 & 6.6 \\
\hline 14 & Rudawa & 294.1 & 30.0 & 0.016 & 1.2 & 0.62 & 8 & 65 & 26 & 0 & 0 & 705 & 8.0 \\
\hline 15 & San & 418.0 & 75.9 & 0.038 & 1.9 & 0.61 & 14 & 1 & 84 & 0 & 0 & 992 & 7.1 \\
\hline 16 & Sękówka & 122.7 & 24.0 & 0.049 & 1.8 & 0.84 & 2 & 29 & 69 & 0 & 0 & 791 & 7.9 \\
\hline 17 & Skawa & 123.7 & 36.8 & 0.037 & 2.4 & 0.77 & 2 & 66 & 32 & 0 & 0 & 840 & 7.0 \\
\hline 18 & Skawica & 143.8 & 19.5 & 0.104 & 2.6 & 0.79 & 1 & 32 & 67 & 0 & 0 & 1207 & 6.5 \\
\hline 19 & Stryszawka & 140.4 & 17.5 & 0.067 & 1.4 & 0.80 & 3 & 45 & 52 & 0 & 0 & 1023 & 6.8 \\
\hline 20 & Uszwica & 268.5 & 55.3 & 0.021 & 1.8 & 0.79 & 4 & 67 & 29 & 0 & 0 & 749 & 8.4 \\
\hline 21 & Wapienica & 52.7 & 18.5 & 0.110 & 1.8 & 0.83 & 9 & 56 & 33 & 0 & 2 & 939 & 8.5 \\
\hline 22 & Wetlina & 131.2 & 17.7 & 0.062 & 2.2 & 0.89 & 0 & 8 & 92 & 0 & 0 & 1115 & 7.2 \\
\hline 23 & Wieprzówka & 151.8 & 29.4 & 0.054 & 2.0 & 0.78 & 7 & 64 & 28 & 0 & 1 & 885 & 7.3 \\
\hline 24 & Wisła & 53.4 & 12.1 & 0.101 & 2.0 & 0.78 & 3 & 14 & 83 & 0 & 1 & 1190 & 7.7 \\
\hline 25 & Wisłok & 143.6 & 27.8 & 0.040 & 1.8 & 0.87 & 0 & 21 & 78 & 0 & 0 & 910 & 7.1 \\
\hline 26 & Woda Ujsolska & 106.6 & 13.8 & 0.079 & 1.3 & 0.72 & 1 & 28 & 70 & 0 & 0 & 1005 & 7.7 \\
\hline 27 & Wołosaty & 118.9 & 28.2 & 0.074 & 1.5 & 0.67 & 0 & 8 & 92 & 0 & 0 & 1033 & 7.1 \\
\hline 28 & Żabniczanka & 23.4 & 4.6 & 0.156 & 2.0 & 0.72 & 0 & 20 & 80 & 0 & 0 & 1094 & 7.8 \\
\hline
\end{tabular}

$A$-catchment area, $L$-length of the main watercourse, $\Psi$-average slope of the catchment area, $D$-river network density, $N$-soil impermeability index, $U R B$ — urban areas, $A G R$ —agricultural areas, $F O R$-forest and semi-natural areas, WET — wetlands, WAT - water bodies, $P_{\text {ave }}$ —average annual rainfall in the catchment area and $t_{\text {ave }}$-average annual temperature in the catchment area.

\section{Materials and Methods}

The study was based on a time series of hydrometric data for 28 study catchments, in the form of daily flows and rainfall, recorded in water gauge sections. Depending on the availability of data strings, their lengths ranged from 19 to 47 years. The data were made available from the Institute of Meteorology and Water Management, National Study Institute in Warsaw. The study was carried out according to the following stages: determining the size of the direct runoff using the NRCS-CN method, determining the $P-C N$ relationship using asymptotic functions, determining the size of the 
$\mathrm{CN}$ parameter taking into account the correction for the fall of the catchment and determining the value of the model work efficiency coefficient.

\subsection{Determination of the Volume of Runoff Using the NRCS-CN Method}

In the NRCS-CN method, the volume of runoff, $Q$, depends on the permeability of the soil substrate, the land of the catchment area and the moisture conditions in the catchment before the rainfall causing the runoff. The volume of direct runoff was determined on the basis of the following relationship [33,34]:

$$
Q=\left\{\begin{array}{c}
\frac{(P-0.2 S)^{2}}{P+0.8 S} \text { when } P \geq 0.2 S \\
0 \text { when } P<0.2 S
\end{array}\right.
$$

where:

$Q$ - direct drain (mm);

$P$-total rainfall $(\mathrm{mm})$;

$S$ - maximum potential catchment retention $(\mathrm{mm})$.

Maximum potential retention of the catchment area, $S$, is directly related to the $C N$ parameter. It is determined from the dependence:

$$
S=25.4\left(\frac{1000}{C N}-10\right)
$$

The moisture of the catchment area prior to the direct runoff-rainfall is expressed as the sum of the five-day runoff-rainfall. This characteristic is expressed by the antecedent moisture condition (AMC) parameter describing three humidity states: dry (AMC I), average (AMC II) and moist (AMC III). In this study, the values of $C N$ parameter (empirical) were determined on the basis of National Engineering Handbook (NEH) [35]. They were determined for all moisture conditions. This parameter was determined as a weighted average for the catchment area, according to the guidelines provided in Reference [36].

\subsection{Determining the Rainfall-CN Parameter Relationship}

To determine the $P-C N$ relationship, asymptotic functions were used. The analysis was based on the observational series of observed rainfall-direct runoff $(P-Q)$ episodes for the study catchments. In the entire analysed multiannual period, after verification for all study catchments, a total of 1408 such episodes were obtained. In the next step, the observed values of the $C N$ parameter $\left(C N_{o b s}\right)$ for individual $P-Q$ episodes were calculated. For this purpose, for each $P-Q$ pair, the volume of $S i$ retention was determined using the formula [37-39]:

$$
S_{i}=5\left[P_{i}+2 Q_{i}-\sqrt{4 Q_{i}^{2}+5 P_{i} Q_{i}}\right]
$$

The observed values of the $C N$ parameter were determined from the formula:

$$
C N_{o b s}=\frac{25400}{254+S_{i}}
$$

where:

$S_{i}$ - episode retention height $(\mathrm{mm}) ;$

$P_{i}$-rainfall for the episode $(\mathrm{mm})$;

$Q_{i}$ - direct runoff in an episode $(\mathrm{mm})$.

In the next step, independent distribution sequences were created for the observed values of $P$ and $Q$, where the analysed variables were aligned in decreasing order. This made it possible to obtain 
the $P$ and $Q$ values with the same return period. For the relations obtained in this way, $C N_{o b s}$ values were determined using Formula (4). In the next stage, the relationship between $C N_{o b s}$ and rainfall $P$ was described using the following models:

Standard Asymptotic CN(ASM) which is described as [40]:

$$
C N(A S M)=C N_{\infty}+\left(100-C N_{\infty}\right) \cdot \exp (-k \cdot P)
$$

where:

$C N_{\infty}$-constant for $P \rightarrow \infty$;

$k$-matching constant;

$P$-rainfall (mm).

The kinetic equation using the decay function $C N$ (Decay) is described as [41]:

$$
C N(\text { Decay })=C N_{L}+\left[b^{1-d}+c \cdot P(d-1)\right]^{\frac{1}{1-d}}
$$

where:

$\mathrm{CN}_{L}$-number of the curve for the highest rainfall;

$b, c, d$-parameters of the equation.

Complementary error function peak $C N(E R F C)$ is expressed by the equation [42]:

$$
C N(E R F C)=C N_{\infty}+b \cdot \operatorname{erfc}\left[\left(\frac{P-c}{d}\right)^{2}\right]
$$

where:

$C N_{\infty}$-constant for $P \rightarrow \infty$;

$b$-amplitude of the density function;

$c$-location parameter;

$d$-scale parameter;

$P$-rainfall (mm).

Equations (5)-(7) and their parameters were determined using the Table 2D Curve software. The parameters were estimated using the least squares method.

In order to determine the stability of the above models, the $A(90)$ coefficient was determined, which is described by the relationship [20]:

$$
A(90)=\frac{C N_{90}}{C N_{\infty, L}}
$$

where:

$\mathrm{CN}_{90}$ - the value of the curve number determined for the 90th rainfall percentile in the distribution series of observations;

$C N_{\infty, L}$ - constant for $P \rightarrow \infty$ or number of the curve for the highest rainfall.

\subsection{Determining the Value of the CN Parameter Taking into Account the Correction for Decrease}

The use of original the $\mathrm{CN}$ parameter, consistent with the NEH [35], is appropriate for catchments with an average decrease of up to $5 \%$. In cases where the catchments are characterised by a greater slope, it is recommended to take into account the correction for slope when determining the $C N$ size [43]. Bearing in mind the mountainous nature of the study catchments, where the average drops were mostly greater than $5 \%$, the study determined empirical values of the $C N$ parameter taking into account the 
correction for the decrease. The Sharpley-Williams [44] approach was used for this, which is described by the following relationship:

$$
C N_{\mathrm{II} \alpha}=a\left(C N_{\mathrm{III}}-C N_{\mathrm{II}}\right)\left(1-b \mathrm{e}^{-c \cdot \alpha}\right)+C N_{\mathrm{II}}
$$

where:

$\mathrm{CN}_{\mathrm{II}}, \mathrm{CNI}_{\mathrm{II}}$-empirical values of the $\mathrm{CN}$ parameter for the average and moist moisture level; $a, b, c$ - equation parameters;

$\alpha$-catchment decline $(\mathrm{m} / \mathrm{m})$.

The original Sharpley-Williams approach, for the parameters $a, b$ and $c$ takes the following values 1/3, 2 and 13.86, respectively. In this study, these parameters were calibrated using the following objective function:

$$
\sum_{i=1}^{n}\left\{Q_{o}-Q_{c a l}\right\}^{2}=\sum_{i=1}^{n}\left\{Q_{o}-\left[\frac{(P-0.2 S)^{2}}{P+0.8 S}\right]^{2}=\right.\text { minimum }
$$

where:

$Q_{0}$-observed direct runoff ( $\left.\mathrm{mm}\right)$;

$Q_{\text {cal }}$-direct runoff calculated (mm).

\subsection{Assessment of the Work Quality of the Analysed Models}

The quality of the analysed models was assessed on the basis of the Nash-Sutcliffe $E$ efficiency coefficient value. This coefficient is described by the relationship [45]:

$$
E=\left[1-\frac{\sum_{i=1}^{i=N}\left(y_{o}-y_{c a l}\right)^{2}}{\sum_{i=1}^{i=N}\left(y_{o}-y_{m}\right)^{2}}\right]
$$

where:

$y_{0}-$ values from observations;

$y_{\text {cal }}$-values calculated using the analysed models;

$y_{m}$-mean value from the observation.

The evaluation of the quality of models' work, in relation to the value of the $E$ coefficient, was made according to the following scale [46]: $0.9<E \leq 1.0$ : very good; $0.80 \leq E \leq 0.90$ : good; $0.65 \leq E<0.80$ : satisfactory; $E \leq 0.65$ : insufficient.

\section{Results and Discussion}

In the first stage of the study, the observed episodes of rainfall-runoff were characterised and the values of the $C N$ parameter were determined. The results are presented in Table 2.

Based on the results summarised in Table 2, it was found that the highest average rainfall during the episodes occurred in the Vistula catchment area; it was $74.2 \mathrm{~mm}$. The lowest average rainfall was observed for the Czarna catchment; it was $21.4 \mathrm{~mm}$. These values should be related to the mean elevation of the catchment area above sea level. Average variability of rainfall (min-max) in the study catchments ranged from $87 \%$ (Wołosaty) to $98 \%$ (Żabniczanka). The magnitude of the mean runoff was clearly related to the volume of rainfall during the episodes. The highest average runoff was recorded for the Vistula; it was $26.7 \mathrm{~mm}$. The lowest was found for the Koprzywianka River, and it was $2.7 \mathrm{~mm}$. This value was mainly determined by land use where agricultural land dominated (77\%) and by soil with an above average permeability. This increases the retention capacity and reduces the volume 
of runoff. In the case of mean values of the observed $C N$ parameter, the highest in the episode was recorded for the Białka River, it was 86.6. The lowest was for the Wołosaty River, and it was 71.7.

Table 2. Characteristics of rainfall-runoff episodes for the study catchments.

\begin{tabular}{|c|c|c|c|c|c|c|c|c|c|c|}
\hline \multirow{2}{*}{ Code } & \multirow{2}{*}{ Catchment } & \multicolumn{3}{|c|}{ Rainfall (mm) } & \multicolumn{3}{|c|}{ Runoff (mm) } & \multicolumn{3}{|c|}{$\mathrm{CN}_{\mathrm{obs}}(-)$} \\
\hline & & Minimum & Average & Maximum & Minimum & Average & Maximum & Minimum & Average & Maximum \\
\hline 1 & Biała & 6.7 & 33.3 & 142.5 & 0.1 & 5.9 & 49.4 & 63.5 & 79.8 & 90.8 \\
\hline 2 & Białka & 5.3 & 53.3 & 262.7 & 0.1 & 24.6 & 170.5 & 71.3 & 86.6 & 93.1 \\
\hline 3 & Bobrza & 6.4 & 34.4 & 98.6 & 0.1 & 8.0 & 33.4 & 71.0 & 82.6 & 91.5 \\
\hline 4 & Czarna & 5.3 & 21.4 & 90.7 & 0.1 & 2.9 & 28.3 & 71.1 & 84.5 & 84.5 \\
\hline 5 & Dunajec & 6.0 & 41.2 & 209.0 & 0.1 & 12.1 & 103.3 & 64.9 & 82.8 & 91.6 \\
\hline 6 & Grajcarek & 4.7 & 38.2 & 106.1 & 0.2 & 10.6 & 43.4 & 71.2 & 83.3 & 94.4 \\
\hline 7 & Kamienica & 6.1 & 52.0 & 241.5 & 0.1 & 16.1 & 123.5 & 62.8 & 80.1 & 91.2 \\
\hline 8 & Koprzywianka & 5.6 & 23.7 & 74.4 & 0.1 & 2.7 & 16.1 & 69.0 & 82.4 & 91.8 \\
\hline 9 & Lepietnica & 6.9 & 45.4 & 198.2 & 0.1 & 18.6 & 98.4 & 66.2 & 86.0 & 91.4 \\
\hline 10 & Lubieńka & 14.3 & 55.4 & 146.9 & 0.1 & 15.6 & 59.4 & 66.7 & 75.3 & 80.8 \\
\hline 11 & Niedziczanka & 7.6 & 45.0 & 146.9 & 0.3 & 14.9 & 65.1 & 69.2 & 83.9 & 91.5 \\
\hline 12 & Ochotnica & 8.3 & 50.5 & 231.3 & 0.1 & 15.6 & 139.1 & 70.4 & 80.3 & 90.4 \\
\hline 13 & Osława & 7.0 & 52.0 & 180.2 & 0.2 & 16.9 & 91.0 & 68.9 & 81.2 & 91.7 \\
\hline 14 & Rudawa & 4.4 & 26.1 & 126.1 & 0.1 & 5.7 & 58.3 & 73.5 & 85.6 & 93.7 \\
\hline 15 & San & 6.4 & 43.5 & 174.1 & 0.1 & 10.5 & 77.2 & 65.5 & 79.9 & 91.7 \\
\hline 16 & Sękówka & 5.8 & 63.5 & 182.8 & 0.3 & 23.5 & 80.5 & 64.2 & 80.6 & 95.5 \\
\hline 17 & Skawa & 4.4 & 40.3 & 222.3 & 0.1 & 15.4 & 136.7 & 72.2 & 86.4 & 94.4 \\
\hline 18 & Skawica & 6.9 & 62.4 & 244.4 & 0.1 & 21.8 & 125.2 & 62.6 & 78.7 & 90.4 \\
\hline 19 & Stryszawka & 5.6 & 63.3 & 274.1 & 0.1 & 21.4 & 156.7 & 64.4 & 78.3 & 92.1 \\
\hline 20 & Uszwica & 5.2 & 43.8 & 92.2 & 0.1 & 15.8 & 35.3 & 74.9 & 85.2 & 93.0 \\
\hline 21 & Wapienica & 4.1 & 62.4 & 208.2 & 0.1 & 24.4 & 101.9 & 64.6 & 81.7 & 94.4 \\
\hline 22 & Wetlina & 7.3 & 50.1 & 162.3 & 0.1 & 10.4 & 73.8 & 67.8 & 75.2 & 89.5 \\
\hline 23 & Wieprzówka & 10.8 & 56.4 & 208.2 & 0.1 & 14.9 & 106.0 & 66.1 & 75.4 & 84.7 \\
\hline 24 & Wisła & 6.8 & 74.2 & 229.7 & 0.1 & 26.7 & 120.9 & 65.0 & 77.0 & 90.6 \\
\hline 25 & Wisłok & 17.1 & 63.2 & 137.8 & 2.9 & 15.5 & 40.1 & 60.3 & 74.7 & 89.2 \\
\hline 26 & $\begin{array}{l}\text { Woda } \\
\text { Ujsolska }\end{array}$ & 9.2 & 47.5 & 90.0 & 0.1 & 8.3 & 24.3 & 68.5 & 75.1 & 87.5 \\
\hline 27 & Wołosaty & 18.7 & 65.7 & 139.5 & 0.7 & 14.9 & 44.4 & 61.9 & 71.7 & 83.9 \\
\hline 28 & Żabniczanka & 4.4 & 64.5 & 247.0 & 0.1 & 23.6 & 125.0 & 61.9 & 80.0 & 94.5 \\
\hline
\end{tabular}

In the next stage of the study, the recorded episodes of rainfall-runoff were compared with the runoff, calculated using the original NRCS-CN method. The results are shown in Figure 2. Analysing the obtained results, it was found that for practically all study catchments, the values of the observed outflows exceeded the upper curve, the course of which was determined by the AMC III parameter. The highest number of exceedances in relation to the total number of observations was found for the Czarna catchment (93\%). Only in the case of the Lubieńka and Wieprzówka catchments did all observations fall within the range defined by the curves from AMC I to AMC III. It should be emphasised that most of the exceedances usually concerned lower rainfall amounts. This is evidenced by the values of the return periods defined for the distribution sequences of rainfall, from which the upper curve was exceeded. Usually, the exceedance concerned rainfall described by smaller return periods. This points to the fact that for smaller rainfall totals, the original NRCS-CN method underestimates the volume of runoff relative to observations. These observations constitute the basic problem of the use of the NRCS-CN method. In order to generate a runoff with low rainfall, a high and constant level of soil moisture should be assumed. Another issue is to define whether, in low rainfall, the resulting runoff is surface or mid-cover. According to Petroselli [13], in addition to the saturation of the soil substrate by infiltration of rainwater, a second mechanism of runoff may occur, i.e., subsurface runoff after the saturated soil layer. Therefore, direct runoff should be treated as a combination of surface and subsurface flow processes. This is confirmed by studies conducted by Dunne and Black [47]. They showed that in the case of low rainfall and permeable soils, there is no surface runoff in the catchments, only subsurface runoff. When analysing the results further, it should be emphasised that in the vast majority of catchments, the ratio of the rainfall, together with the smaller, calculated amounts of runoff, was significantly greater than the observations, exceeding $50 \%$. For all catchment areas, except 
Wapienica where no exceedances were observed, it was lower than $50 \%$ and amounted to $43 \%$. In the case of larger rainfall totals, the observations were a definite overestimation of the runoff size in relation to the observations. The identified differences may be the reason for the methodological approach of the original NRCS-CN method itself. It was developed on the basis of the maximum annual daily rainfall totals [48]. On the other hand, rainfall causing direct runoff was assumed for the calculations. When analysing the obtained results, it was also observed that in the vast majority of study catchments (22), the observations focused around the curve, where the $C N$ parameter was estimated for AMC II. In the Białka, Czarna, Grajcarek, Lepietnica, Uszwica and Wapienica catchments, the observations focused mainly on the AMC III curve. These results can be explained by the fact that the level of soil moisture in mountain catchments is influenced not only by rainfall but also by the geological structure, high level of groundwater and soil with limited infiltration capacity, which significantly reduces the catchment retention capacity. Therefore, during rainfall, it does not undergo the process of infiltration but is immediately transformed into surface flow that increases the level of AMC.
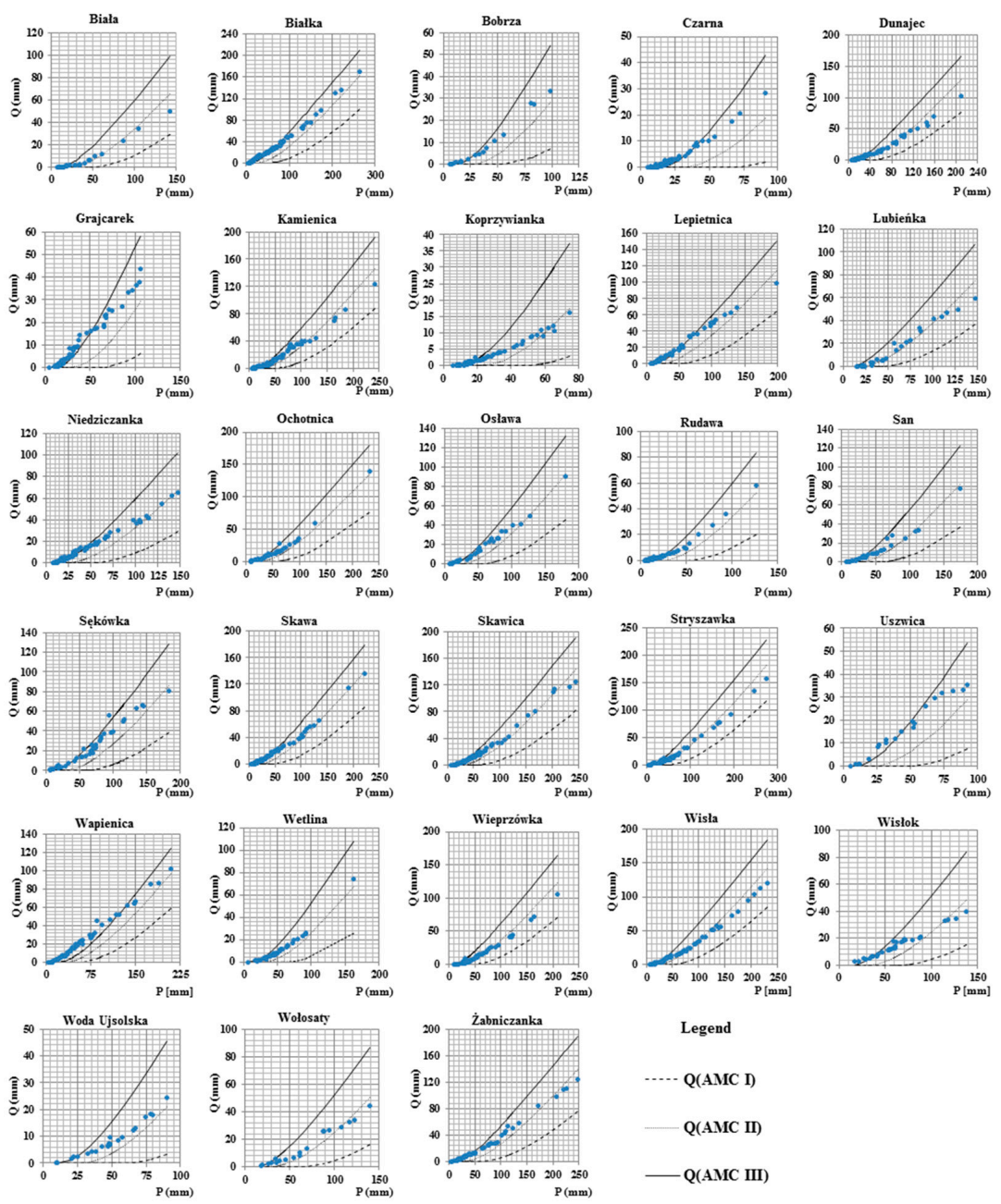

Figure 2. Observed rainfall-runoff relations against the background of the calculated values. AMC = antecedent moisture condition, a parameter describing three humidity states: dry (AMC I), average (AMC II) and moist (AMC III).

In the next stage of the study, the impact of rainfall on the observed values of the $\mathrm{CN}$ parameter was determined. The relationship was also approximated using the models described by Equations (5)-(7). The results are shown in Figure 3. 

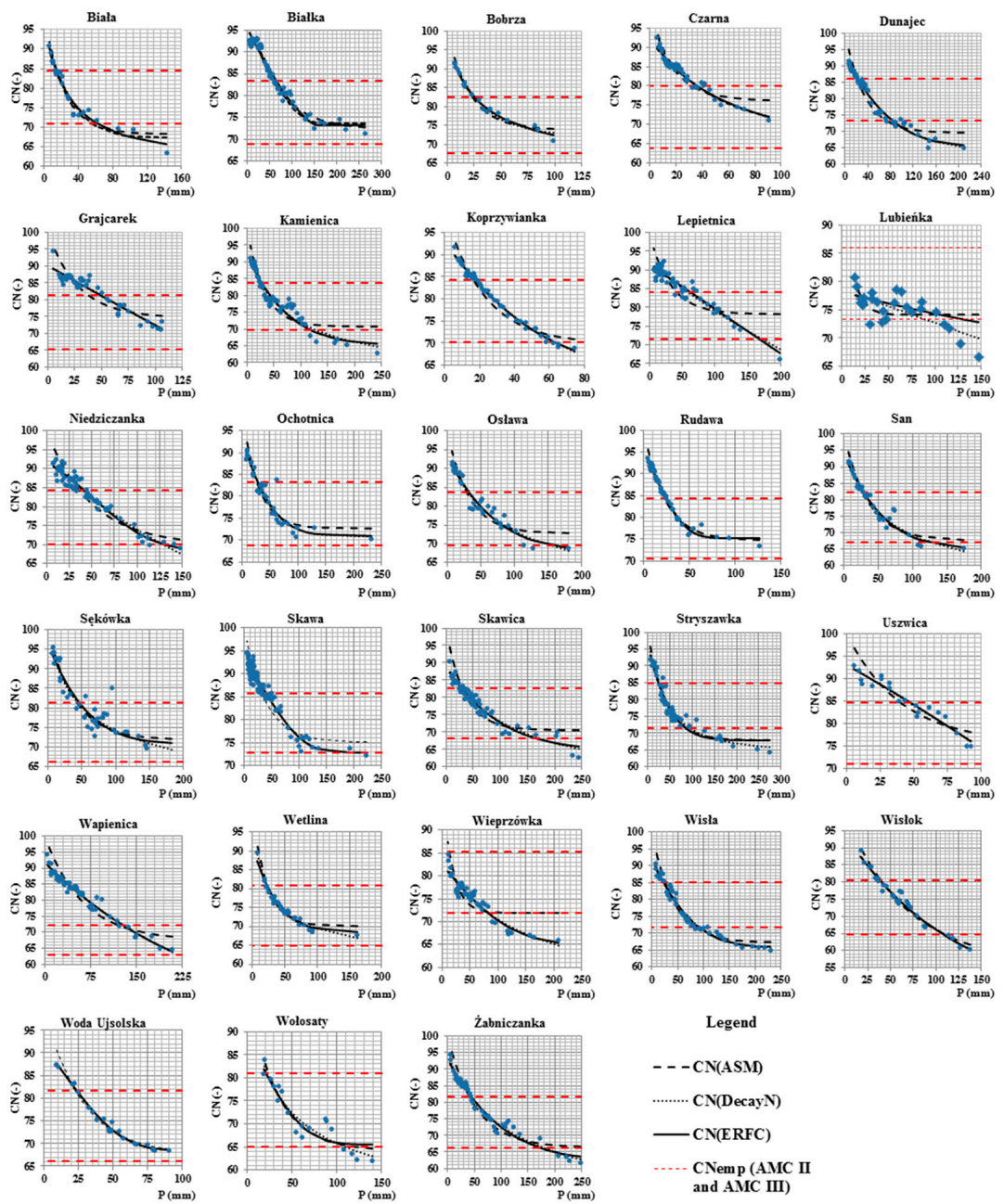

Figure 3. Relationships between the curve number $(C N)$ parameter and rainfall against the background of approximated models.

Analysing the results in Figure 3, it was found that there was a relationship between the observed $C N$ parameter and rainfall $P$. The course of the observations clearly indicated an inverse relationship. With the increase in rainfall, the value of $C N$ decreased; therefore, the highest values of the observed $\mathrm{CN}$ were obtained for the lowest rainfall episodes. In order for low rainfall to cause direct runoff, the catchment area should have a sufficiently high level of moisture. Moreover, it should show a limited infiltration capacity of rainfall. Hence, relatively low rainfall was associated with high $\mathrm{CN}$ [48]. Lower and more stable values of the observed $C N$ for higher rainfall may be determined mainly by the use of the catchment area and the spatial distribution of arable lands. Study catchments are mainly covered by agricultural land and forests. They showed greater retention capacity and the ability to delay the runoff. Comparing the mean $C N$ values observed with the empirical values of this characteristic for AMC II, it can be noticed that in each catchment, the mean values from the observations were much higher. On the other hand, for extremely high rainfall, the $C N$ values observed were close to the $\mathrm{CN}$ values determined for AMC II. Hence, it is stated that for rainfall with a lower return period, the assumption of a moderate degree of moisture in the catchment area may lead to a significant underestimation of the runoff. However, in the case of rainfall with high repetition periods, the assumption of AMC II seems to be justified. On the one hand, it is recommended to adopt AMC III in ungauged catchments. This reduces the risk of underestimating the size of design flows $[49,50]$. However, it also indicates that in the case of designing unstructured objects, the assumption of AMC II is sufficient. The discrepancies between the empirical values of $C N$ and the observed values of this characteristic were also demonstrated by Randusová et al. [51]. Lal et al. [52] showed that the empirical 
values of $\mathrm{CN}$ were not consistent with those estimated on the basis of the rainfall-runoff relationship. $\mathrm{He}$ also confirmed that the NRCS-CN method gives much better results for high rainfall events. Oliveira et al. [53] also indicated significant disproportions between the empirical and the observed CN. In the case of catchments with greater slopes, it is suggested to take into account the correction for slope in the calculations [54]. When further analysing the relationship between rainfall and the observed $C N$, it can be noticed that most of the study catchments ( $75 \%$ of all catchments) showed a tendency to stabilise the observed $C N$ for extremely high rainfall. Hence, in these catchments the $P-C N$ relationship can be described as standard. This is one of the most common relationships, especially in agricultural catchments [55]. Similar results were obtained by D'Asaro and Grillone [56] and D'Asaro et al. [57], who demonstrated standard $P-C N$ behaviour in $70 \%$ of study catchments. The obtained results were confirmed by the study by Hawkins [20] that also showed that approximately $70 \%$ of the catchments were characterised by a standard relationship between rainfall and the observed $C N$. In the case of the seven studied catchments, i.e., Grajcarek, Lepietnica, Lubieńka, Sękówka, Uszwica, Wapienica and Wisłok, the observed $C N$ was not stable for high rainfall. These catchments showed the so-called complacent behaviour. As reported by Kowalik and Wałega [48], the reason for such a relationship may be the exposure of the catchment area. When they are exposure mainly south, the phenomenon of evaporation from the soil is intensified, which directly affects the acceleration of the surface drying processes, limiting the moisture conditions of the catchment. Such a relationship may also be influenced by the density of the river network, which is directly related to the permeability of the substrate. These catchments are characterised by a high impermeability index and relatively high annual rainfall, which causes a strong development of the river network (over $1.4 \mathrm{~km} \cdot \mathrm{km}^{-2}$ ). Such catchments are characterised by a shorter concentration time and an increased supply of the watercourse by groundwater, which influences the change the shape of the runoff hydrograph.

In the next stage of the study, the quality of the models used to describe the $P-C N$ dependency in the study catchments was analysed: standard asymptotic model (5), kinetic equation using the decay function (6) and complementary error function peak (7). The results are presented in Table 3.

Based on the results summarised in Table 3 , it was found that the kinematic equation with the use of the decay function was the best suited function to describe the $P-C N$ relationship. This is evidenced by the values of the Nash-Sutcliffe coefficient, which had the highest value for this model in 21 catchments. In the remaining eight (i.e., Lepietnica, Niedziczanka, Rudawa, Uszwica, Wapienica, Wieprzówka and Woda Ujsolska), the complementary error function peak turned out to be the best match. Despite the fact that the standard asymptotic model was in no case indicated as the best-suited function to describe the analysed dependency, it was also characterised by a very high quality. In the case of catchments Lepietnica, Lubieńka and Wieprzówka, the value of the $E$ coefficient below 0.65 clearly indicated an insufficient quality of work of the standard asymptotic model. In the case of the kinematics equation using the decay function, the insufficient quality of the model's work according to the $E$ coefficient was found only in the Lubieńka catchment area (value $E$ below 0.65 ). The $P-C N$ dependency in the Sékówka, Wieprzówka and Wołosaty catchments had good quality for the kinematics equation (E from 0.8 to 0.9 ). In the case of the other catchments, the values of the $E$ coefficient clearly exceeded 0.9 , which indicates a very good quality of the model's work. When analysing the complementary error function peak model, it can be concluded that, as in the case of other functions, this model was characterised by insufficient quality of work in the Lubieńka catchment area (E coefficient below 0.65). A good quality of the model's work was recorded in the catchments of Sekówka and Wołosaty ( $E$ value from 0.8 to 0.9 ). In the remaining catchments, the model's work quality was very good (value of the $E$ coefficient above 0.9 ). The good fit of the analysed models to the description of the $P-C N$ dependency was also evidenced by the high values of the $R^{2}$ determination coefficients. Lower values of these characteristics were found only in catchments that also had lower values of the $E$ coefficient. 
Table 3. The results of the quality analysis of the models describing the $P$-CN relationship.

\begin{tabular}{|c|c|c|c|c|c|c|c|c|c|c|c|c|c|}
\hline \multirow{2}{*}{ Code } & \multirow{2}{*}{ Catchment } & \multicolumn{2}{|c|}{$\mathrm{CN}_{\infty}$} & \multirow{2}{*}{$\frac{\mathrm{CN}_{\mathrm{L}}}{6}$} & \multicolumn{3}{|c|}{$E(-)$} & \multicolumn{3}{|c|}{$R^{2}(-)$} & \multicolumn{3}{|c|}{$\mathrm{A}(90)(-)$} \\
\hline & & 5 & 7 & & 5 & 6 & 7 & 5 & 6 & 7 & 5 & 6 & 7 \\
\hline 1 & Biała & 68.2 & 67.3 & 61.0 & 0.938 & 0.957 & 0.950 & 0.942 & 0.957 & 0.950 & 0.958 & 0.856 & 0.945 \\
\hline 2 & Białka & 72.3 & 73.7 & & 0.906 & 0.963 & 0.906 & 0.930 & 0.963 & 0.968 & 0.949 & 0.961 & 0.967 \\
\hline 3 & Bobrza & 73.8 & 72.7 & 58.8 & 0.964 & 0.988 & 0.981 & .969 & 0.988 & 0.981 & .989 & 0.787 & 0.974 \\
\hline 4 & Czarna & 76.3 & 69.8 & 52.5 & 0.842 & 0.947 & 0.943 & 0.861 & 0.947 & 0.943 & 0.954 & 0.657 & 0.873 \\
\hline 5 & Dunaj & & 65.2 & & 0.909 & 0.980 & 0.979 & .929 & 0.980 & 0.979 & .962 & 0.885 & 0.903 \\
\hline 6 & Grajca & 4.6 & 41.8 & 89 & 0.726 & 0.914 & 0.914 & .755 & 0.910 & 0.910 & 0.997 & 0.346 & 0.558 \\
\hline 7 & & 70.7 & & & & 0.940 & 0.923 & 0.879 & 0.940 & 0.923 & 0.986 & 0.735 & 0.923 \\
\hline 8 & & & & & & 0.989 & & & 0.988 & & .953 & 0.705 & 0.874 \\
\hline 9 & & 78.1 & 29.8 & & & 0.944 & 0.950 & 0.698 & 0.944 & 0.952 & .988 & 0.351 & 0.377 \\
\hline 10 & & 74.0 & & & & 0.535 & & 302 & 0.535 & & 0.974 & 0.510 & 0.839 \\
\hline 11 & Niedzic & 69.9 & 68.7 & & & 0.979 & 0.984 & 0.914 & 0.979 & 0.984 & 0.964 & 0.601 & 0.948 \\
\hline 12 & Ochot & 72.7 & 71.0 & & 0.919 & 0.963 & 0.963 & 0.934 & 0.963 & 0.963 & 0.996 & 0.971 & 0.973 \\
\hline 13 & & & & & & 0.948 & & & 0.948 & & 0.985 & 0.6 & 0.920 \\
\hline 14 & & 74.7 & 75. & & 64 & 0.983 & & 970 & 0.983 & 0.985 & .971 & 0.976 & 0.978 \\
\hline 15 & & 67.6 & 65.1 & 56.6 & & 0.955 & & & 0.955 & & .956 & & 0.920 \\
\hline 16 & & & & & & 0.878 & & & 0.878 & 0.8 & .985 & 0.589 & 0.971 \\
\hline 17 & & 75.1 & 72 & & & 0.970 & & 0.893 & 0.970 & 0.9 & 0.990 & 0.967 & 0.961 \\
\hline 18 & & & & & & 0.953 & & & 0.953 & & 0.992 & & 0.928 \\
\hline 19 & & 67.8 & 67. & & 0.9 & 0.970 & 0.962 & 0.962 & 0.970 & 0.962 & .983 & 0.925 & 0.983 \\
\hline 20 & & 75.6 & -47.7 & 14.2 & & 0.926 & 0.930 & 0.921 & 0.926 & 0.930 & 0.973 & 0.182 & -0.613 \\
\hline 21 & & & & & & 0.967 & & & 0.967 & & 0.962 & & 0.716 \\
\hline 22 & & 70.1 & 68.5 & & 0.938 & 0.981 & 0.969 & 0.946 & 0.981 & 0.969 & 0.999 & 0.854 & 0.976 \\
\hline 23 & Wieprzówka & 71.9 & 64.9 & 58.3 & 0.592 & 0.899 & 0.900 & 0.625 & 0.899 & 0.900 & 0.946 & 0.857 & 0.955 \\
\hline 24 & & 67.2 & & & & 0.973 & & & 0.973 & & & & 0.980 \\
\hline 25 & & 56.1 & 48.3 & 19.9 & 0.959 & 0.973 & 0.973 & 0.959 & 0.971 & 0.988 & 0.870 & 0.309 & 0.749 \\
\hline 26 & $\begin{array}{c}\text { Woda } \\
\text { Ujsolska }\end{array}$ & 67.5 & 68.5 & 68.6 & 0.959 & 0.987 & 0.988 & 0.967 & 0.987 & 0.988 & 0.980 & 0.995 & 0.993 \\
\hline 27 & Wołosaty & 64.2 & 65. & 45. & 0.875 & 0.895 & 0.863 & 0.877 & 0.916 & 0.865 & 0.985 & 0.965 & 0.721 \\
\hline 28 & Żabniczanka & 66.3 & 62.4 & 42.2 & 0.917 & 0.973 & 0.969 & 0.935 & 0.973 & 0.935 & 0.940 & 0.599 & 0.885 \\
\hline
\end{tabular}

$C \overline{N_{\infty}, C N_{L} \text { - the curve number parameter for the largest rainfall in particular models; } E \text {-Nash-Sutcliffe efficiency }}$ coefficient value; $R^{2}$ —coefficient of determination; $A(90)$-model's stabilisation coefficient.

The proposed functions are based on the $C N_{\infty}$ and $C N_{L}$ values, which may be an alternative to the empirical values of the $C N$ parameter in the NRCS-CN method. In the vast majority of catchments, $C N_{\infty}$ and $C N_{L}$ were more similar to the empirical $C N$ defined for AMC II. This value is usually used for design purposes. In the case of the $C N$ function (ASM), only in three catchments was the $C N_{\infty}$ closer to the empirical $C N$ for AMC III, i.e., Czarna, Grajcarek and Lepietnica. In the case of the remaining models, the $C N_{\infty}$ and $C N_{L}$ values were more similar to the empirical $C N$ for AMC II. When analysing the differences between $C N \infty$ and $C N_{L}$ and the empirical $C N$ for AMC II, it should be emphasised that in the case of the $C N$ model (ASM), only for eight catchments were they observed to be negative. In the case of the $C N$ (Decay) and $C N$ (ERFC) models, negative differences were observed in a much larger number of catchments, i.e., 23 and 19, respectively. This points to the fact that in the case of the standard asymptotic model, assuming the $C N_{\infty}$ as a design value, being an alternative to the empirical CN AMC II, may increase the risk of overestimating the volume of direct runoff. However, in the case of the $C N$ (Decay) and CN (ERFC) models, the volume of direct runoff may be underestimated. Similar results for the analysis of $C N_{\infty}$ obtained with the asymptotic model in the catchments of the Upper Vistula Basin were obtained by Wałega et al. [58]. The authors also showed that there were significant differences between the $C N$ describing high rainfall and that of AMC II. It should also be emphasised that in some study catchments, the $C N_{\infty}$ and $C N_{L}$ values reached unrealistic values. This case concerns the $C N$ (Decay) function for the Grajcarek, Lepietnica, Lubieńka, Niedziczanka, Uszwica and Żabniczanka catchments. This situation was also found for the $C N$ function (ERFC) in the catchments of Lepietnica, Osława, Sękówka, Uszwica, Wapienica and Wisłok. In the remaining catchments, it can be assumed that the determined values of $C N_{\infty}$ and $C N_{L}$ were close to the empirical $\mathrm{CN}$ corresponding to the average moisture content of the catchment area. The possibility of using the $C N_{\infty}$ and $C N_{L}$ parameters as an alternative to the empirical $C N$ may occur when this value is close to the $C N$ determined for very high rainfall. Since usually most of the hydrometric observations are described with a return period below the design requirements, it is necessary to extrapolate beyond 
the observed rainfall-runoff events. Hence, the functions used to describe the $P-C N$ relation are used. One of the possibilities of verifying the applied functions is the measure $A(90)$ which describes the ratio of $C N_{\infty}$ or $C N_{L}$ to the observed $C N$, determined for the 90th percentile rainfall in the distribution sequence of observations. This ratio means what part of the observations can be described by the analysed functions. In the case of the $C N$ function (ASM), the value of $A$ (90) was above 0.90 for almost all catchments. Only for the Wisłok catchment was it 0.87 . Despite the fact that stable results were obtained in the case of the asymptotic function, the use of this model in the estimation of $C N$ size should be approached with caution. This is evidenced by the values of the $E$ coefficients specified for this model. The opposite situation was found for the remaining functions. Despite the obtained high values of the $E$ coefficients, the values of $A(90)$ show that the results are less stable than in the case of the asymptotic function. For CN (Decay), the value of A (90) below $50 \%$ was found for five catchments. In the case of eight catchments, the value of this ratio was from $50 \%$ to $75 \%$. The remaining catchments had $A$ (90) values above $75 \%$. In the case of $C N$ (ERFC), the ratio $A$ (90) was below $50 \%$ for two catchments. In the case of three catchments, the ratio of A (90) ranged from $50 \%$ to $75 \%$. The other values were above $75 \%$. Despite the obtained high values of the $E$ coefficients for $C N$ (Decay) and $C N$ (ERFC), these functions should not be used in catchments where low $A$ (90) values were obtained. These values were obtained primarily in catchments characterised by complacent behaviour. Therefore, the analysed functions should be used only in catchments described by the standard $P-C N$ relation. A study on the possibility of using the analysed functions to describe the $P-C N$ relationship in the catchments of the Upper Vistula Basin was also conducted by Wałega et al. [41]. The authors also showed that the $C N$ (Decay) and $C N$ (ERFC) functions were characterised by a very high quality of work. However, it was confirmed that these models did not sufficiently describe the $P-C N$ relationship for high rainfall (lack of stability of the $C N$ parameter).

The study was supplemented with the determination of the volume of direct runoff, using the NRCS-CN method, with the use of the catchment gradient correction for the empirical $C N$ parameter. The obtained results were compared with the runoff values determined for the empirical $C N$, with the assumed AMC II. The results of the calculations are presented in Figure 4.

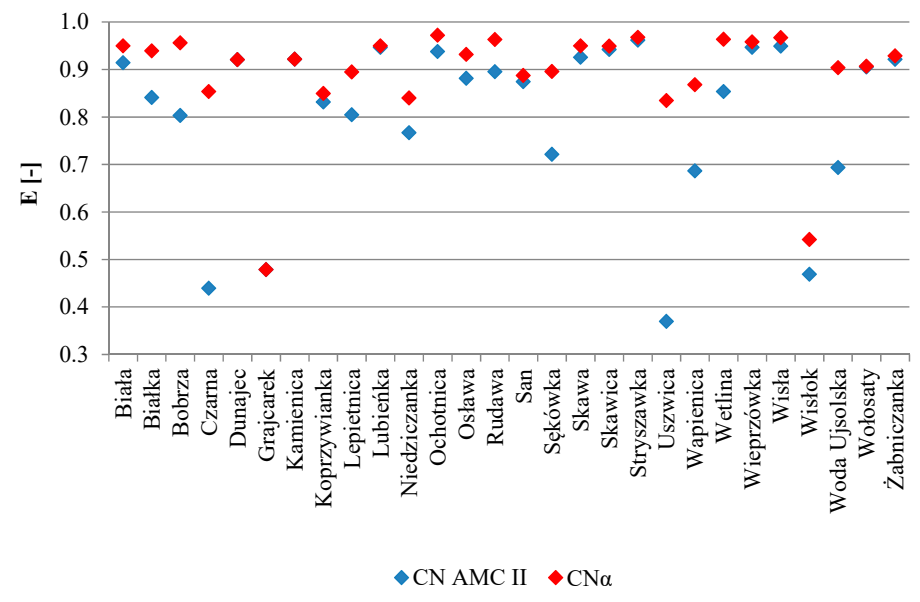

Figure 4. Influence of the correction on the catchment decrease in the work quality of the Natural Resources Conservation Service (NRCS)-CN model.

When analysing the obtained results, it can be generally stated that the application of the slope correction increased the work quality of the NRCS-CN method in estimating the volume of direct runoff. This was evidenced by the values of the $E$ coefficient determined for the analysed variants. The lowest values of $E$ coefficient were for Czarna, Grajcarek, Uszwica and Wisłok. This mean that the assumed CN parameter for AMC II was too low (slope adjustment is for CN AMC II). This situation may be caused because the catchment soil moisture level is determined not only by the precipitation, but also by the high level of the ground water table, which can be maintained after the winter period, leading to 
a reduced catchment retention capacity as well as poorly permeable soils that make precipitation infiltration more difficult. Hence, the rainfall reached already moist soil. It should be emphasised that applying the slope adjustment in Czarna and Uszwica improves the quality of the model's work. Despite the small differences between the values of the $E$ coefficients, in the 12 catchments, the use of the correction for the decline made it possible to improve the quality of the NRCS-CN model. The greatest improvement was found for the Uszwica catchment, where the correction for the decline made it possible to change the quality class from insufficient to good. In the Sekówka catchment area, there was a change in the quality of work from sufficient to good. In the catchments of Bobrza, Czarna, Osława, Rudawa, San, Sekówka and Uszwica, the quality of the model's work improved from good to very good. It should be noted that most of the catchments where the quality improved were located in the upland and flat regions of the Upper Vistula Basin, which are characterised by smaller drops. In the remaining catchments, the application of the correction for the decline did not change the quality class of the model's work. In most cases, this class remained at a very good level. Studies related to the use of the model (8) to determine the correction for the decrease in the CN parameter were also conducted by Ajmal et al. [59]. The authors also modified the original method proposed by Sharpley-Williams [44] by calibrating the parameters of the equation with respect to local runoff conditions. On the basis of observations, they found that the inclusion of the correction for the slope significantly improved the quality of the model but only when the volume of initial losses was estimated as 0.2 of the maximum potential retention of the catchment area. It should be emphasised that the influence of the catchment slopes on the size of the direct runoff is a questionable matter. It is commonly believed that as the slope increases, direct runoff increases. It is directly related to the increase in its velocity, reduction of surface retention, glen infiltration capacity and shorter time of water remaining on the slopes [60,61]. On the other hand, the decrease in the volume of runoff with an increase in the fall of the catchment area may be indicated by the decrease in the supply of rainwater to a unit of the catchment area and an increase in soil skeletal structure [62].

\section{Conclusions}

The aim of this study was to verify the $C N$ parameter for 28 catchments located in the Upper Vistula Basin. The standard asymptotic model, kinetic equation and complementary error function were used for the analysis. On the basis of the conducted study, it was found that there was a strong relationship between the direct runoff and the rainfall that caused it. The observed runoff volumes were usually similar to those calculated with the NRCS-CN model for AMC II. The analysis showed that the empirical values of the $C N$ parameter differed from the values determined on the basis of the volume of rainfall and runoff. The vast majority $(75 \%)$ of the study catchments were characterised by the standard behaviour of the $P-C N$ relation, which indicates the stabilisation of the $C N$ parameter for higher rainfall. In the remaining cases, complacent behaviour was found. It was also found that the kinetic model was the best model to describe the $P-C N$ relationship. In most catchments, it was found that the specific $C N_{\infty}$ and $C N_{L}$ values were similar to the empirical $C N$ for AMC II. It was also noted that the highest stability of the analysed functions, expressed by parameter A (90), was achieved for the standard asymptotic model. The analysis of the application of the correction factor for the empirical $\mathrm{CN}$ in relation to the study catchments showed that it usually increased the quality of the models used, even in catchments with smaller slopes. Hence, it is recommended to consider the use of correction factors when the runoff is determined for the empirical $C N$. The conducted study is significant from the point of view of engineering hydrology, especially in ungauged catchments. The NRCS-CN method is the most widely used to determine net rainfall which is the basic input signal for rainfall-runoff models, e.g., NRCS-UH or Snyder. The rainfall-runoff models allow for the determination of hydrographs for the design of hydrotechnical structures or flood management, mostly in ungauged catchments. This is especially important for the study region due to the fact of its flooding nature. The performed analyses clearly confirmed that one should be very careful with the tabulated values of the $C N$ parameter, which results mainly from the methodology of their development. Therefore, future study should focus 
on updating them in relation to the physiographic and meteorological characteristics of the catchment area, taking into account their diversity. Considering the constantly progressing urbanization, the factors influencing rainfall in such catchments should be analysed in detail.

Author Contributions: Conceptualization, D.M.; methodology, D.M.; software, D.M.; validation, D.M.; formal analysis, D.M.; investigation, D.M.; resources, D.M.; data curation, D.M.; writing-original draft preparation, D.M.; writing - review and editing, D.M. and A.W.; visualization, D.M.; supervision, A.W.; project administration, D.M.; funding acquisition, D.M. All authors have read and agreed to the published version of the manuscript.

Funding: This research was funded by National Science Centre, Poland, grant number 2019/03/X/ST10/00065.

Conflicts of Interest: The authors declare no conflict of interest.

\section{References}

1. Schneiderman, E.M.; Steenhuis, T.S.; Thongs, D.J.; Easton, Z.M.; Zion, M.S.; Neal, A.L.; Mendoza, G.F.; Walter, M.T. Incorporating variable source area hydrology into a Curve-Number-based watershed model. Hydrol. Process. 2007, 21, 3420-3430. [CrossRef]

2. Gaál, L.; Szolgay, J.; Lapin, M.; Faško, P. Hybrid approach to delineation of homogeneous regions for regional precipitation frequency analysis. J. Hydrol. Hydromech. 2009, 57, 226-249. [CrossRef]

3. Zhang, W.Y. Application of NRCS-CN method for estimation of watershed runoff and disaster risk. Geomat. Nat. Hazards Risk 2019, 10, 2220-2238. [CrossRef]

4. Amatya, D.M.; Wałęga, A. Long-term Data-the Key for Evaluating Runoff Peak Discharge Estimation Tools and Parameters for Watersheds on Forest Lands. Adv. Civ. Eng. Technol. 2020, 4, 1-5.

5. Fan, F.; Deng, Y.; Hu, X.; Weng, Q. Estimating composite curve number using an improved SCS-CN method with remotely sensed variables in Guangzhou, China. Remote Sens. 2013, 5, 1425-1438. [CrossRef]

6. Wałega, A.; Rutkowska, A. Usefulness of the Modified NRCS-CN Method for the Assessment of Direct Runoff in a Mountain Catchment. Acta Geophys. 2015, 63, 1423-1446. [CrossRef]

7. Jung, J.W.; Yoon, K.S.; Choi, D.H.; Lim, S.S.; Choi, W.J.; Choi, S.M.; Lim, B.J. Water management practices and SCS curve numbers of paddy fields equipped with surface drainage pipes. Agric. Water Manag. 2012, 110, 78-83. [CrossRef]

8. Ozdemir, H.; Elbaşi, E. Benchmarking land use change impacts on direct runoff in ungauged urban watersheds. Phys. Chem. Earth A/B/C 2015, 79-82, 100-107. [CrossRef]

9. Babu, P.S.; Mishra, S.K. Improved SCS-CN-inspired model. J. Hydrol. Eng. 2012, 17, 1164-1172. [CrossRef]

10. Grimaldi, S.; Petroselli, A.; Romano, N. Green-Ampt Curve-Number mixed procedure as an empirical tool for rainfall-runoff modelling in small and ungauged basins. Hydrol. Process. 2013, 27, 1253-1264. [CrossRef]

11. Singh, P.K.; Mishra, S.K.; Berndtsson, R.; Jain, M.K.; Pandey, R.P. Development of a modified SMA based MSCS-CN model for runoff estimation. Water Resour. Manag. 2015, 29, 4111-4127. [CrossRef]

12. Ogden, F.L.; Hawkins, R.; Walter, M.T.; Goodrich, D.C. Comment on “Beyond the SCS-CN method: A theoretical framework for spatially lumped rainfall-runoff response" by M. S. Bartlett et al. Water Resour. Res. 2017, 53, 6345-6350. [CrossRef]

13. Petroselli, A. A generalization of the EBA4SUB rainfall-runoff model considering surface and subsurface flow. Hydrol. Sci. J. 2020, 66, 2390-2401. [CrossRef]

14. Szymczak, T.; Krężałek, K. Prognostic model of total runoff and its components from a partially urbanized small lowland catchment. Acta Sci. Pol. Form. Circumiectus 2018, 18, 185-203. [CrossRef]

15. Wałega, A.; Amatya, D.M. Modification of the SME-CN method for predicting event runoff and peak discharge from a drained forest watershed on the North Carolina tlantic coastal plain. Trans. ASABE 2020, 63, 275-278. [CrossRef]

16. Caletka, M.; Šulc Michalková, M.; Karásek, P.; Fučík, P. Improvement of SCS-CN Initial Abstraction Coefficient in the Czech Republic: A Study of Five Catchments. Water 2020, 12, 1964. [CrossRef]

17. Moon, G.; Ajmal, M.; Ahn, J.; Kim, T.W. Investigating practical alternatives to the NRCS-CN method for direct runoff estimation using slope-adjusted curve numbers. KSCE J. Civ. Eng. 2016, 20, 3022-3030. [CrossRef]

18. Ebrahimian, M.; Nuruddin, A.A.B.; Soom, M.A.; Neng, L.J. Runoff estimation in steep slope catchment with standard and slope-adjustment Curve Number Method. Pol. J. Environ. Stud. 2012, 21, 1191-1202. 
19. Shi, W.; Wang, N. An Improved SCS-CN Method Incorporating Slope, Soil Moisture, and Storm Duration Factors for Runoff Prediction. Water 2020, 12, 1335. [CrossRef]

20. Hawkins, R.H. Asymptotic determination of Curve Numbers from data. J. Irrig. Drain. Eng. 1993, 119, 334-345. [CrossRef]

21. Soulis, K.X.; Valiantzas, J.D. SCS-CN parameter determination using rainfall-runoff data inheterogeneous watersheds-the two-CN system approach. Hydrol. Earth Syst. Sci. 2012, 16, 1001-1015. [CrossRef]

22. Wałęa, A.; Devendra, D.M.; Caldwell, P.; Marion, D.; Panda, S. Assessment of storm direct runoff and peak flow rates using improved SCS-CN models for selected forested watersheds in the Southeastern United States. J. Hydrol. Reg. Stud. 2020, 27, 100645. [CrossRef]

23. Ebrahimian, A.; Gulliver, J.S.; Wilson, B.N. Estimating effective impervious area in urban watersheds using land cover, soil character and asymptotic curve number. Hydrol. Sci. J. 2018, 63, 513-526. [CrossRef]

24. Ryu, J.; Jang, W.S.; Kim, J.; Choi, J.D.; Engel, B.A.; Yang, J.E.; Lim, K.J. Development of a Watershed-Scale Long-Term Hydrologic Impact Assessment Model with the Asymptotic Curve Number Regression Equation. Water 2016, 8, 153. [CrossRef]

25. Velásquez-Valle, M.A.; Sánchez-Cohen, I.; Hawkins, R.H.; Serna-Pérez, A.; Gutiérrez-Luna, R.; Pedroza-Sandoval, A. Rainfall-runoff relationships in a semiarid rangeland watershed in central Mexico, based on the CN-NRCS approach. Model. Earth Syst. Environ. 2017, 3, 1263-1272. [CrossRef]

26. Santikari, V.P.; Murdoch, L.C. Including effects of watershed heterogeneity in the curve number method using variable initial abstraction. Hydrol. Earth Syst. Sci. 2018, 22, 4725-4743. [CrossRef]

27. Krajewski, A.; Sikorska-Senoner, A.E.; Hejduk, A.; Hejduk, L. Variability of the Initial Abstraction Ratio in an Urban and an Agroforested Catchment. Water 2020, 12, 415. [CrossRef]

28. Młyński, D.; Wałęga, A.; Książek, L.; Florek, J.; Petroselli, A. Possibility of Using Selected Rainfall-Runoff Models for Determining the Design Hydrograph in Mountainous Catchments: A Case Study in Poland. Water 2020, 12, 1450. [CrossRef]

29. Wałęga, A.; Cupak, A.; Amatya, D.M.; Drożdżal, E. Comparison of direct outflow calculated by modified scs-cn methods for mountainous and highland catchments in upper Vistula basin, Poland and lowland catchment in South Carolina, USA. Acta Sci. Pol. Form. Circumiectus 2017, 16, 187-207. [CrossRef]

30. Kohnová, S.; Rutkowska, A.; Banasik, K.; Hlavčová, K. The L-moment based regional approach to curve numbers for Slovak and Polish Carpathian catchments. J. Hydrol. Hydromech. 2020, 68, 170-179. [CrossRef]

31. Rutkowska, A.; Kohnová, S.; Banasik, K.; Szolgay, J.; Karabová, B. Probabilistic properties of a curve number: A case study for small Polish and Slovak Carpathian Basins. J. Mt. Sci. 2015, 12, 533-548. [CrossRef]

32. Młyński, D.; Cebulska, M.; Wałega, A. Trends, Variability, and Seasonality of Maximum Annual Daily Precipitation in the Upper Vistula Basin, Poland. Atmosphere 2018, 9, 313. [CrossRef]

33. Xiao, B.; Wang, Q.; Fan, J.; Han, F.; Dai, Q. Application of the SCS-CN Model to Runo_Estimation in a Small Watershed with High Spatial Heterogeneity. Pedosphere 2011, 26, 738-749. [CrossRef]

34. Soulis, K.X. Estimation of SCS Curve Number variation following forest fires. Hydrol. Sci. J. 2018, 63, 1332-1346. [CrossRef]

35. NRCS (Natural Resources Conservation Service). National Engineering Handbook Section-4, Part 630, Hydrology; NRCS: Washington, DC, USA, 2001.

36. Wałęga, A.; Salata, T. Influence of land cover data sources on estimation of direct runoff according to SCS-CN and modified SME methods. Catena 2019, 172, 232-242. [CrossRef]

37. Gajbhiye, S.; Mishra, S.K.; Pandey, A. Relationship between SCS-CN and Sediment Yield. Appl. Water Sci. 2014, 4, 363-370. [CrossRef]

38. Ajmal, M.; Kim, T.W.; Ahn, J.H. Stability assessment of the curve number methodology used to estimate excess rainfall in forest-dominated watersheds. Arab. J. Geosci. 2016, 9, 402. [CrossRef]

39. Ryu, J.; Jung, Y.; Kong, D.S.; Park, B.K.; Kim, Y.S.; Engel, B.A.; Lim, K.J. Approach of Land Cover Based Asymptotic Curve Number Regression Equation to Estimate Runoff. Irrig. Drain. 2016, 65, 94-104. [CrossRef]

40. Singh, P.; Mishra, S.K. Determination of curve number and estimation of runoff using Indian experimental rainfall and runoff data. J. Spat. Hydrol. 2017, 13, 1-26.

41. Wałęga, A.; Michalec, B.; Cupak, A.; Grzebinoga, M. Comparison of SCS-CN determination methodologies in a heterogeneous catchment. J. Mt. Sci. 2015, 12, 1084-1094. [CrossRef]

42. Banasik, K.; Krajewski, A.; Sikorska, A.; Hejduk, L. Curve Number estimation for a small urban catchment from recorded rainfall-runoff events. Arch. Environ. Prot. 2014, 40, 75-86. [CrossRef] 
43. Mishra, S.K.; Chaudhary, A.; Shrestha, R.K.; Pandey, A.; Lal, M. Experimental verification of the effect of slope and land use on scs runoff curve number. Water Res. Manag. 2014, 28, 3407-3416. [CrossRef]

44. Sharpley, A.; Williams, J. Epic_Erosion/Productivity Impact Calculator: I. Model Documentation. II: User Manual; Technical Bulletin, No. 1768 1990; United State Department of Agriculture: Washington, DC, USA, 1990.

45. Nash, J.E.; Sutcliffe, J.V. River flow forecasting through conceptual models part I-A discussion of principles. J. Hydrol. 1970, 10, 282-290. [CrossRef]

46. Ritter, A.; Muñoz-Carpena, R. Performance evaluation of hydrological models: Statistical significance for reducing subjectivity in goodness-of-fit assessments. J. Hydrol. 2013, 480, 33-45. [CrossRef]

47. Dunne, T.; Black, R.D. An Experimental Investigation of Runoff Production in Permeable Soils. Water Resour. Res. 1970, 6, 478-490. [CrossRef]

48. Kowalik, T.; Wałęga, A. Estimation of CN Parameter for Small Agricultural Watersheds Using Asymptotic Functions. Water 2015, 7, 939-955. [CrossRef]

49. Młyński, D. Analysis of Problems Related to the Calculation of Flood Frequency Using Rainfall-Runoff Models: A Case Study in Poland. Sustainability 2020, 12, 7187. [CrossRef]

50. De Paola, F.; Ranucci, A.; Feo, A. Antecedent moisture condition (SCS) frequency assessment: A case study in southern Italy. Irrig. Drain. 2013, 62, 61-71. [CrossRef]

51. Randusová, B.; Marková, R.; Kohnová, S.; Hlavčová, K. Comparison of cn estimation approaches. Int. J. Eng. Res. Sci. 2015, 1, 34-40.

52. Lal, M.; Mishra, S.K.; Pandey, A.; Pandey, R.P.; Meena, P.K.; Chaudhary, A.; Kumar, J.R.; Shreevastava, A.K.; Kumar, Y. Evaluation of the Soil Conservation Service curve number methodology using data from agricultural plots. Hydrogeol. J. 2017, 25, 151-167. [CrossRef]

53. Oliveira, P.T.S.; Nearing, M.A.; Hawkins, R.H.; Stone, J.J.; Rodrigues, D.B.B.; Panachuki, E.; Wendland, E.J. Curve num-ber estimation from Brazilian Cerrado rainfall and runoff data. Soil Water Conserv. 2016, 71, 420-429. [CrossRef]

54. Deshmukh, D.S.; Chaube, U.C.; Hailu, A.E.; Gudeta, D.A.; Kassa, M.T. Estimation and comparision of curve numbers based on dynamic land use land cover change, observed rainfall-runoff data and land slope. J. Hydrol. 2013, 492, 89-101. [CrossRef]

55. Muche, M.E.; Hutchinson, S.L.; Hutchinson, J.M.; Johnston, J.M. Phenology-adjusted dynamic curve number for improved hydrologic modeling. J. Environ. Manag. 2019, 1, 403-413. [CrossRef] [PubMed]

56. D'Asaro, F.; Grillone, G. Empirical Investigation of Curve Number Method Parameters in the Mediterranean Area. J. Hydrol. Eng. 2012, 17, 1141-1152. [CrossRef]

57. D'Asaro, F.; Grillone, G.; Hawkins, R.H. Curve Number: Empirical evaluation andcomparison with Curve Number handbook tables in Sicily. J. Hydrol. Eng. 2014, 19, 04014035. [CrossRef]

58. Wałęa, A.; Młyński, D.; Wachulec, K. The use of asymptotic functions for determining empirical values of CN parameter in selected catchments of variable land cover. Stud. Geotech. Mech. 2017, 39, 111-120. [CrossRef]

59. Ajmal, M.; Wassem, M.; Kim, D.; Kim, T.W. A Pragmatic Slope-Adjusted Curve Number Model to Reduce Uncertainty in Predicting Flood Runoff from Steep Watersheds. Water 2020, 12, 1469. [CrossRef]

60. Huang, M.; Gallichand, J.; Wang, Z.; Goulet, M. A modification to the soil conservation service curve number method for steep slopes in the Loess Plateau of China. Hydrol. Process. 2006, 20, 579-589. [CrossRef]

61. Fang, H.; Cai, Q.; Chen, H.; Li, Q. Effect of rainfall regime and slope on runo_in a gullied loess region on the Loess Plateau in China. Environ. Manag. 2008, 42, 402-411. [CrossRef]

62. Mah, M.; Douglas, L.; Ringrose-Voase, A. Effects of crust development and surface slope on erosion by rainfall. Soil Sci. 1992, 154, 37-43. [CrossRef]

Publisher's Note: MDPI stays neutral with regard to jurisdictional claims in published maps and institutional affiliations. 